\title{
Risk Management Tools for Emergencies in the Context of Global Informatization
}

\author{
SERGII KHOLOD ${ }^{1}$, GANNA IEFIMOVA², YULIIA HALYNSKA ${ }^{3}$, VIKTORIYA MARHASOVA ${ }^{4}$, \\ HAMED RASHED SAYED ABDULLAH ALNUAIMI ${ }^{5}$, \\ TALEB ABDULLAH MOHAMMED ALI ALHAMMADI*6 \\ ${ }^{1}$ Department of Innovative Management and Financial Analytics, ALFRED NOBEL UNIVERSITY, UKRAINE \\ ${ }^{2}$ Department of Economy Policy and Safety, ADMIRAL MAKAROV NATIONAL UNIVERSITY OF SHIPBUILDING, \\ UKRAINE \\ ${ }^{3}$ Department of International Economic Relations, SUMY STATE UNIVERSITY, UKRAINE \\ ${ }^{4}$ Department of Theoretical and Applied Economics, CHERNIHIV POLYTECHNIC NATIONAL UNIVERSITY, \\ UKRAINE \\ ${ }^{5,6}$ Department of Accounting, Analysis and Audit, ODESSA NATIONAL POLYTECHNIC UNIVERSITY, UKRAINE \\ *E-mail: alhammadi.t@ukr.net
}

\begin{abstract}
Global informatization has brought many changes to all spheres of life. At the turn of the century, it becomes clear that along with tremendous technical achievements and radical geopolitical changes, the outgoing era's main result was a change in the world's systemic properties. Ensuring safety in emergency situations is one of the most critical tasks of modern human development. The risks from these events can be catastrophic, which is why the authors devoted their research to the study of the theoretical and methodological foundations, as well as the development of recommendations for improving risk management tools in emergency management in the context of global informatization.
\end{abstract}

Keywords: ecology, emergencies, risk management, water resources.

JEL Classification: D81, M15, Q57 


\section{Introduction.}

The most important directions in the development of civilization at all stages of its existence have been and remain issues of achieving a higher standard of living, ensuring the well-being and safety of the population and the environment (Albornoz \& Chen, 2021; Ibrahim et al, 2021). These priorities continue to this day. However, the importance of safety and its weight in the overall quality of life has grown significantly. The processes taking place in the course of the development of society inevitably give rise to various dangerous phenomena (Mura et al, 2015; Seilerová, 2019). Analysis of information on emergencies, taking into account the structure of threats and the dynamics of their changes, shows that natural disasters caused by hazardous natural phenomena, fires, as well as human-made accidents and disasters are the main threats to the safety of the population and the environment, and therefore to the sustainable development of the whole society and the environment.

Current economic conditions are characterized by an increasing role of risks, which are increasingly becoming global. Modern researchers, who consider the theory of risks and emergencies from the point of view of nonlinear dynamics, argue that ensuring safety in the current environment is necessary to closely monitor changes in our world's systemic properties (Margasova \& Rogovyi, 2010; Filyppova et al, 2019).

At the turn of the century, it becomes clear that along with tremendous technological advances and radical geopolitical changes, the outgoing era's main result was a change in the world's systemic properties (Prokopenko \& Miśkiewicz, 2020). A complex system as a whole may acquire properties that its parts do not possess. In today's rapidly developing world, hundreds of thousands of causal relationships are created and destroyed (a long chain of which can lead to the system beginning to behave in a paradoxical way), and new development resources and new risks are associated with them. New methods of struggle have appeared, new areas of rivalry, new security threats.

\section{Research methods and models.}

\subsection{The concept of risk and risk management.}

The number of features inherent in modern society, namely global digitalization, instability, market changes, etc., cause uncertainty and uncertainty in obtaining the desired end result. Therefore, the current conditions of global informatization are characterized by increased risk.

The term "risk" comes from Latin resecō - "cut off", "reduce" or ancient Greek. jıłıkóv "danger". In Italian, rischio is a danger, a threat; risikare - to advance among the rocks; in Spanish, riesgo - possibility of a mishap or misfortune, of someone or something suffering harm or damage; in the French - risque - a threat, risk (literally - to go around the rock) (Bashynska \& Levinska, 2017). The variety of factors that determine the occurrence of risks is related to both the specifics of a particular phenomenon and the general features of society's uncertainty.

Risk factors (so-called risk-forming factors) reflect a set of processes and phenomena that contribute to the emergence of a particular risk, i.e. it is the driving forces (causes) that give rise to risk processes. To generalize the causes of risk, there is a classification of risk factors depending on such features as the scale of impact, the ability to identify and manage risk, the nature of the origin and impact (Fig. 1).

It should be noted that there are also some, including international standards for the organization of risk management (Gavurova et al, 2021).

All standards in risk management are currently divided into international standards; standards developed by professional associations and standards developed by national standardization bodies. 
Figure 1. Classification of risk factors

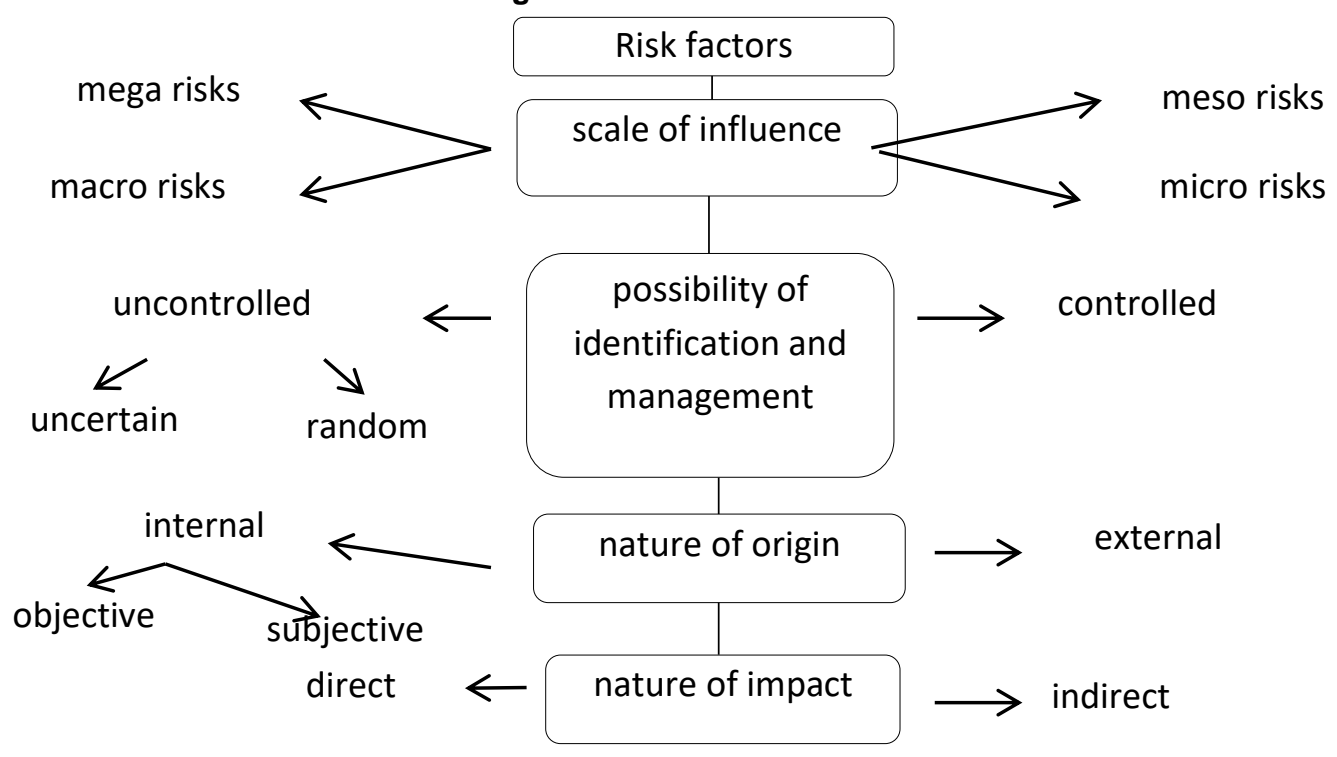

\subsection{World practice of risk management standardization.}

Note that within the existing standards of risk management also offers different approaches to the organization of risk management in enterprises.

The risk management process by risk management standards FERMA: 2002, COSO: 2004, ISO 31000: 2009 are presented in Table. 1.

Note that the issue of risk management arises in almost all standards governing the scope of human activity. In risk theory, several different methods reduce the degree of risk and the amount of damage (Saługa, 2020). By themselves, the methods of risk management are quite diverse. This is due to the ambiguity of the concept of risk and the presence of many criteria for their classification.

\subsection{Emergency and emergency risks.}

Emergency - a violation of normal living conditions and activities of people in facilities or territories, caused by an accident, catastrophe, epidemic, natural disaster, epizootic, epiphytosis, large fire, the use of means of destruction that have caused or may lead to human and material losses, as well as large-scale infection of humans and animals.

According to the Code of Civil Protection of Ukraine, an emergency is a situation on a separate territory or business entity on it or a water body, which is characterized by the violation of normal living conditions caused by a catastrophe, accident, fire, natural disaster, epidemic, epizootic, epitope, the use of means of destruction or another dangerous event that has led (may lead) to a threat to life or health of the population, a large number of dead and injured, causing significant material damage, as well as the impossibility of living in such an area or facility, conducting economic activities on it (Halkiv et al, 2020; Kuzmenko et al, 2019).

Emergencies can be classified according to the nature or cause of the occurrence, source of occurrence, and the scale and extent of the damage. In fig. 2 shows the classification of emergencies.

By the nature of the cause of occurrence:

1) conflict (intentional, intentional) emergencies result from military social and other conflicts, as well as terrorist acts, extremist and other intentional acts.

2) conflict-free (accidental, unintentional) - this group includes natural disasters, as well as most human-made accidents and disasters. 
Table 1. Risk management standards

\begin{tabular}{|c|c|c|c|}
\hline & & management standards & \\
\hline \multirow{7}{*}{ 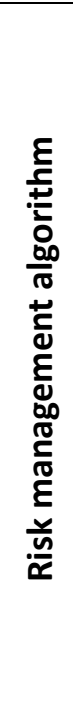 } & FERMA & coso & ISO 31000 \\
\hline & I. Strategic goals & $\begin{array}{l}\text { I. Definition of the internal } \\
\text { environment }\end{array}$ & $\begin{array}{l}\text { I. Definition of the } \\
\text { environment }\end{array}$ \\
\hline & $\begin{array}{l}\text { II. Risk assessment: } \\
\text { a) risk analysis } \\
\text { - risk identification; } \\
\text { - risk analysis; } \\
\text { - risk assessment. } \\
\text { b) quantitative/qualitative risk } \\
\text { assessment }\end{array}$ & $\begin{array}{l}\text { II. Goal setting } \\
\text { III. Definition of events } \\
\text { IV. Risk assessment }\end{array}$ & \multirow[t]{5}{*}{$\begin{array}{l}\text { II. Risk assessment: } \\
\text { - risk identification; } \\
\text { - risk analysis; } \\
\text { - risk assessment. } \\
\text { III. Impact of risk }\end{array}$} \\
\hline & III. Risk report & V. Risk response & \\
\hline & IV. Decision-making & VI. Means of control & \\
\hline & V. Measures & $\begin{array}{l}\text { VII. Information and } \\
\text { communication }\end{array}$ & \\
\hline & VI. Risk re-report & VIII. Monitoring & \\
\hline
\end{tabular}

Figure. 2. Classification of emergencies

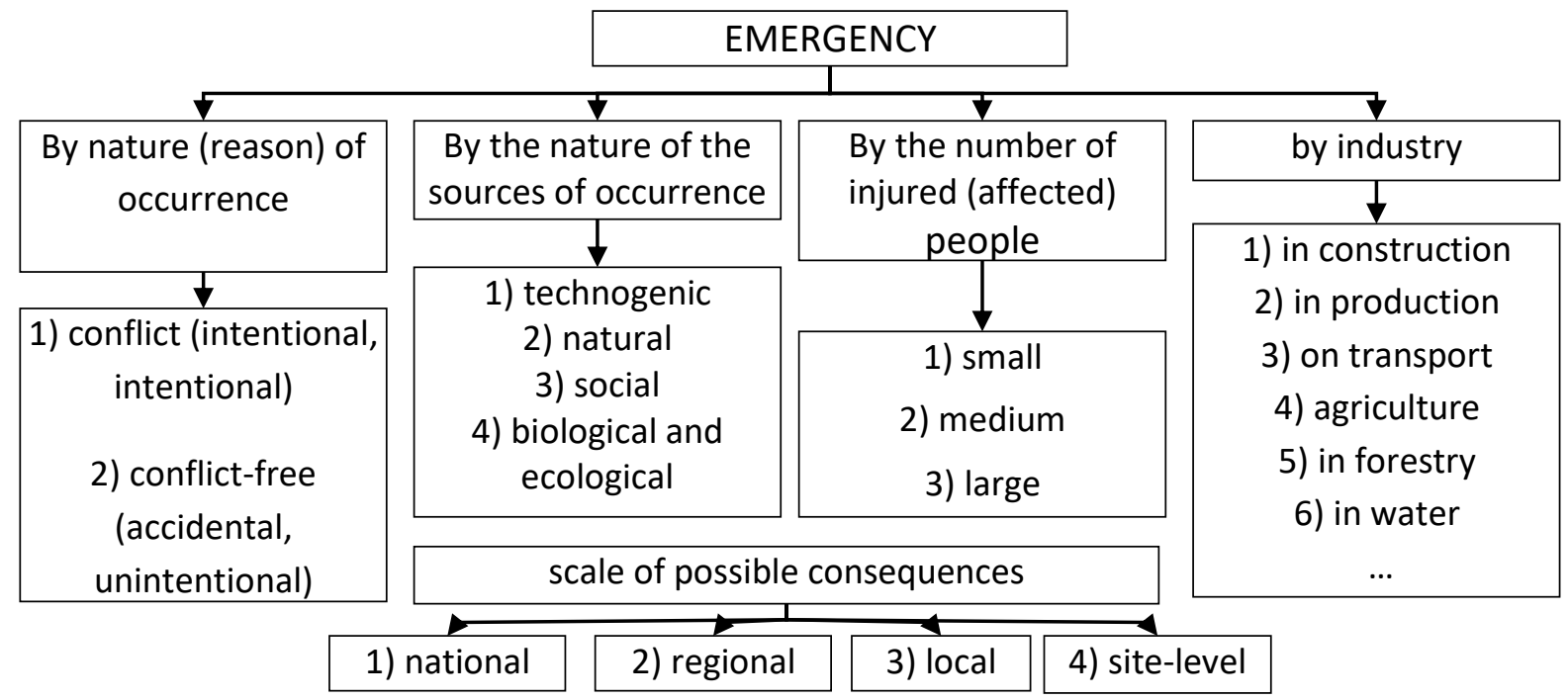

Simultaneously, one should not erroneously assume that "random" emergencies cannot be predicted and cannot be natural. So, for example, flooding during the flood-hazardous season, forest fires during the fire-hazardous season.

By the nature of the sources of occurrence, emergencies are divided into:

1) technogenic emergencies, the origin of which is associated with technical objects: explosions, fires, accidents at chemically hazardous facilities, radioactive substances emissions at radiationhazardous facilities, accidents with the release of environmentally hazardous substances, the collapse of buildings, accidents on life support systems, transport accidents, etc.

2) natural emergencies associated with the manifestation of nature's elemental forces: earthquakes, tsunamis, floods, volcanic eruptions, landslides, mudflows, hurricanes, tornadoes, storms, natural fires.

3) social emergencies - events generated by society and occurring in society: interethnic conflicts with the use of force, terrorism, robberies, violence, contradictions between states (wars), famine, etc. 
4) biological and ecological emergencies are caused by changes in the state of the land, atmosphere, hydrosphere, biosphere as a result of human activity, as well as epidemics, epizootics, epiphytotic (Gibesova et al., 2017).

According to experts, depending on the number of victims (affected) people, we can identify the following main categories of emergencies:

Small - the number of victims from 25 to 100 people, of whom 10-15 require hospitalization;

Medium - victims from 100 to 1000 people, subject to hospitalization from 25 to 250 people;

Large - more than 1,000 people were injured, more than 250 people are hospitalized.

According to the third main feature "scale of possible consequences" emergencies are divided, taking into account the territorial distribution, nature and type of forces and means involved in the elimination of consequences, into:

National emergency - when an emergency develops in two or more oblasts or threatens crossborder relocation, as well as when its elimination requires materials and technical resources in excess of its own capabilities of a particular area, but not less than one per cent of expenditures the relevant budget.

Table 2. Classification of emergencies by scale of losses

\begin{tabular}{|c|c|c|c|c|c|c|}
\hline \multirow{2}{*}{$\begin{array}{l}\text { Affected } \\
\text { direction, } \\
\text { industry }\end{array}$} & \multirow[b]{2}{*}{ Criteria } & \multirow[b]{2}{*}{ Unit } & \multicolumn{4}{|c|}{ Thresholds for level: } \\
\hline & & & Object & Local & Regional & General state \\
\hline \multirow{2}{*}{$\begin{array}{l}\text { Material objects } \\
\text { of } \\
\text { infrastructure, } \\
\text { industry, } \\
\text { transport, } \\
\text { housing and } \\
\text { communal } \\
\text { services }\end{array}$} & $\begin{array}{l}\text { 1. The share of } \\
\text { destroyed } \\
\text { (expected } \\
\text { destruction) } \\
\text { fixed assets }\end{array}$ & $\begin{array}{l}\text { Percentage of } \\
\text { fixed assets } \\
\text { related to } \\
\text { emergencies }\end{array}$ & $\begin{array}{l}\text { Until } \\
10\end{array}$ & From 10 & From 15 & Over 25 \\
\hline & $\begin{array}{l}\text { 2. Economic } \\
\text { losses }\end{array}$ & Percentage & & to 15 & to 25 & $\begin{array}{l}\text { More than } 1 \\
\text { percent of the } \\
\text { consolidated } \\
\text { regional } \\
\text { budget }\end{array}$ \\
\hline \multirow{4}{*}{$\begin{array}{l}\text { Population } \\
\text { (facility staff, } \\
\text { residents of } \\
\text { residential } \\
\text { buildings, } \\
\text { passengers of } \\
\text { vehicles, etc.) }\end{array}$} & $\begin{array}{l}\text { 1.A. Number of } \\
\text { victims }\end{array}$ & Persons & $\begin{array}{l}\text { Until } \\
20\end{array}$ & $\begin{array}{l}\text { Up to } 1 \\
\text { percent of } \\
\text { the } \\
\text { consolidated } \\
\text { local budget }\end{array}$ & $\begin{array}{l}\text { Up to } 1 \\
\text { percent of } \\
\text { the } \\
\text { consolidated } \\
\text { regional } \\
\text { budget }\end{array}$ & $\begin{array}{l}\text { More than } \\
300\end{array}$ \\
\hline & $\begin{array}{l}\text { B. Number of } \\
\text { people killed } \\
\text { (except for } \\
\text { road accidents) }\end{array}$ & Persons & 1 & From 20 & From 50 & Over 5 \\
\hline & $\begin{array}{l}\text { B. Significant } \\
\text { deterioration } \\
\text { of living } \\
\text { conditions for a } \\
\text { long time }\end{array}$ & Persons & $\begin{array}{l}\text { Up to } \\
100\end{array}$ & up to 50 & up to 300 & $\begin{array}{l}\text { More than } \\
3000\end{array}$ \\
\hline & $\begin{array}{l}\text { 2. The amount } \\
\text { of } \\
\text { compensation }\end{array}$ & Percentage & & $1-2$ & From 3 & $\begin{array}{l}\text { More than } 1 \\
\text { percent of the } \\
\text { consolidated } \\
\text { regional } \\
\text { budget }\end{array}$ \\
\hline
\end{tabular}


Emergencies of the regional level - when an emergency unfolds on the territory of two or more administrative districts (cities of regional subordination) of the Autonomous Republic of Crimea, oblasts, cities of Kyiv and Sevastopol or threatens to transfer to the adjacent region of the state, as well as and technical resources in excess of the individual district's capacity, but not less than one per cent of the expenditures of the respective budget.

Local emergency - when an emergency that goes beyond a potentially dangerous object threatens the spread of the situation itself or its secondary effects on the environment, neighbouring settlements, engineering structures, as well as when its elimination requires material and technical resources in volumes exceeding own possibilities of a potentially dangerous object, but not less than one per cent of the volume of expenses of the corresponding budget. The local level includes all emergencies that occur at housing and communal facilities and others that are not included in the approved lists of potentially dangerous objects.

Site-level emergencies - when emergencies do not fall under the above definitions.

The general characteristics of the classification of emergencies to the appropriate level by the criterion of the amount of caused or expected economic damage to infrastructure, industry, transport, housing and communal services and the population (personnel, occupants, occupants, passengers, etc.) are given below.

Table 3. Classification of natural disasters by the severity of consequences for the population and objects of the national economy

\begin{tabular}{|c|c|c|c|c|}
\hline \multirow[t]{2}{*}{$\begin{array}{c}\text { Emergency } \\
\text { category }\end{array}$} & \multicolumn{2}{|c|}{$\begin{array}{l}\text { The nature of } \\
\text { management }\end{array}$} & \multirow{2}{*}{$\begin{array}{l}\text { The nature of the consequences } \\
\text { (emergency maximum. The number of } \\
\text { direct losses) }\end{array}$} & \multirow{2}{*}{$\begin{array}{c}\text { Probable } \\
\text { number pe } \\
\text { year }\end{array}$} \\
\hline & $\begin{array}{l}\text { Recovery } \\
\text { degree }\end{array}$ & $\begin{array}{l}\text { Recovery } \\
\text { time }\end{array}$ & & \\
\hline The easiest & Fully & Up to 3 days & $\begin{array}{l}\text { Disrupted communications, the number of } \\
\text { losses up to } n \cdot 10 \text { people. Another damage } \\
\text { is small. }\end{array}$ & $N \cdot 10$ \\
\hline Light (weak) & Fully & Up to 1 year & $\begin{array}{l}\text { Damage to communications, enterprises, } \\
\text { buildings, settlements, crop losses, etc. The } \\
\text { number of losses up to } n \cdot 102-n \cdot 103 \\
\text { people. }\end{array}$ & $N \cdot 1$ \\
\hline Medium & Fully & $\begin{array}{l}\text { Up to } 5-7 \\
\text { years }\end{array}$ & $\begin{array}{l}\text { Damage and destruction of settlements, } \\
\text { enterprises, and crops loss, but without } \\
\text { significant damage to the environment. The } \\
\text { number of losses up to } n \cdot 104-n \cdot 106\end{array}$ & $x$ \\
\hline $\begin{array}{l}\text { Strong } \\
\text { (heavy) }\end{array}$ & $\begin{array}{l}\text { Not } \\
\text { completely }\end{array}$ & $\begin{array}{l}\text { More than } 5- \\
7 \text { years }\end{array}$ & $\begin{array}{l}\text { Various losses with significant population } \\
\text { losses. Number of victims up to } n \cdot 105-n \cdot \\
106 .\end{array}$ & $x$ \\
\hline Destructive & $\begin{array}{l}\text { Not } \\
\text { recoverable }\end{array}$ & $\begin{array}{l}\text { Not } \\
\text { recoverable }\end{array}$ & $\begin{array}{l}\text { Various losses with the loss of the natural } \\
\text { basis lead to the loss of the territorial } \\
\text { complex. }\end{array}$ & $x$ \\
\hline
\end{tabular}

\subsection{Emergency risk management.}

Emergency risk management performs functions inherent in any management activity. Still, the specifics of their implementation is determined by the object of management - water resources, soil, etc. - forecasting (planning), organization, control, regulation, coordination and motivation. 
Risk management forecasting is the development for the future of changes in the object's state as a whole and its various parts. Forecasting is the prediction of a particular event. Forecasting can be done using statistical (by extrapolation) and expert methods (based on anticipation of change, using experts' experience and intuition). Thus, forecasting can be carried out both based on extrapolation of the past into the future, taking into account the expert assessment of trends and the direct prediction of changes. These changes may occur suddenly. Management based on anticipation of these changes requires the development of a manager's sense of mechanism and intuition and making flexible operational decisions.

The organization's function in risk management is the formation and implementation of a program of action aimed at reducing risk based on certain rules and procedures specific to a particular emergency.

Regulation in risk management impacts the object of management, which achieves a state of stability of this object in the event of deviations from the specified parameters. The regulation covers mainly current measures to eliminate emerging deviations.

Coordination in risk management ensures the coherence of all the risk management system, management staff and specialists.

Motivation in risk management is the process of motivating entities to take an interest in the results of their work.

Control in risk management is to check the organization of work to reduce the degree of risk, which requires an analysis of the effectiveness of measures to assess actions' effectiveness.

The characteristic familiarity of such risky is the systemic power, and the realization of this can be infused onto the country's border at once, that immense hour-long horizon of the day (up to 10 and more rockets) - change the price of the oversight of the situation. The World Economic Forum (WEF) has published an annual report on the main risks the world may face in 2020. The organization has identified five major threats: a slowing economy and social tensions, climate change, declining biodiversity, cybersecurity challenges and emerging public health challenges. Climate change has also become stronger and faster than many expected: natural disasters are becoming more powerful and more frequent. Global warming threatens with increased mortality, lack of food and water, social and geopolitical tensions, increased migration and negative impact on the economy. It was towards the environment/ecology that the emphasis on the need for risk management shifted (Fig. 3 and 4).

Figure 3. Top 5 Global Risks in Terms of Likelihood, 2011-2020 (World Economic Forum, 2020)

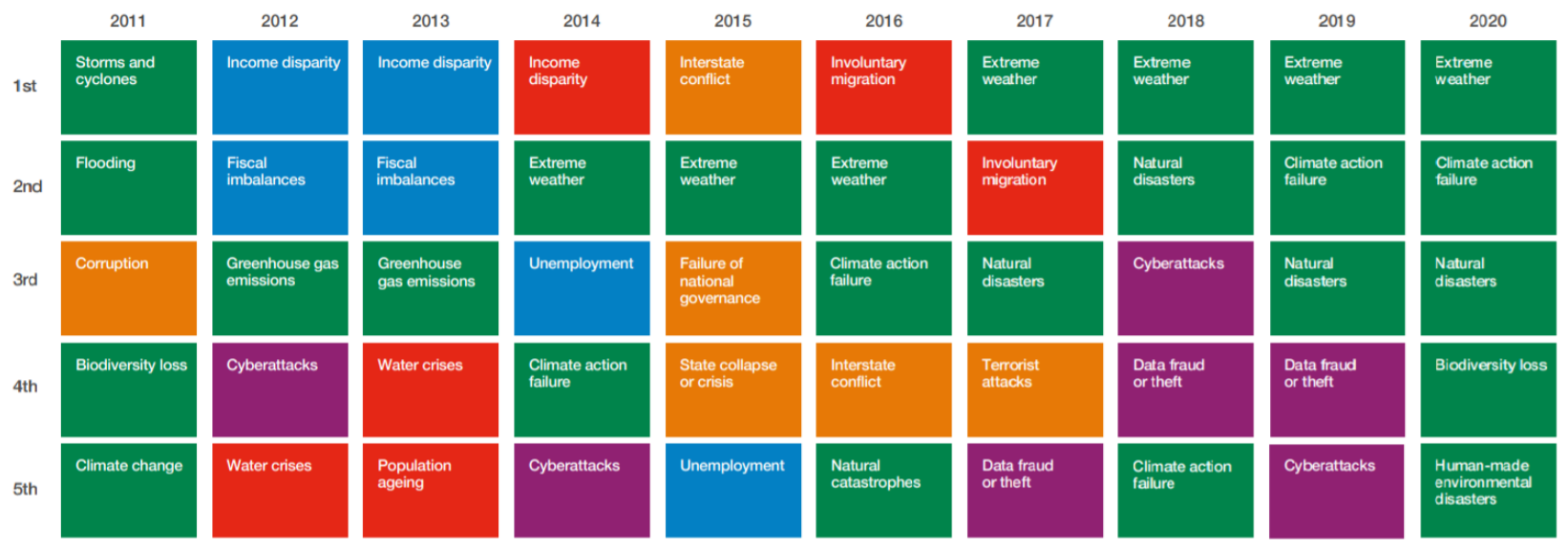

Even though the risk is usually associated with the possibility of incurring losses, it is incorrect to study it only on the opposing side. Risk plays a role in the socio-economic life of society, which is manifested in such functions as Figure 4.

The innovative function is manifested in the fact that risk forces the business entity to use nontraditional (innovative) ways of organizing business activities to avoid or minimize risks. This creates the preconditions for launching innovative activities, which has positive consequences for consumers 
(in the form of innovative products and services), a particular company (in the form of profit) and for the country as a whole increasing its competitiveness in foreign markets.

Figure 4. Pareto diagram (generated by the authors based on the World Economic Forum, 2020 data)

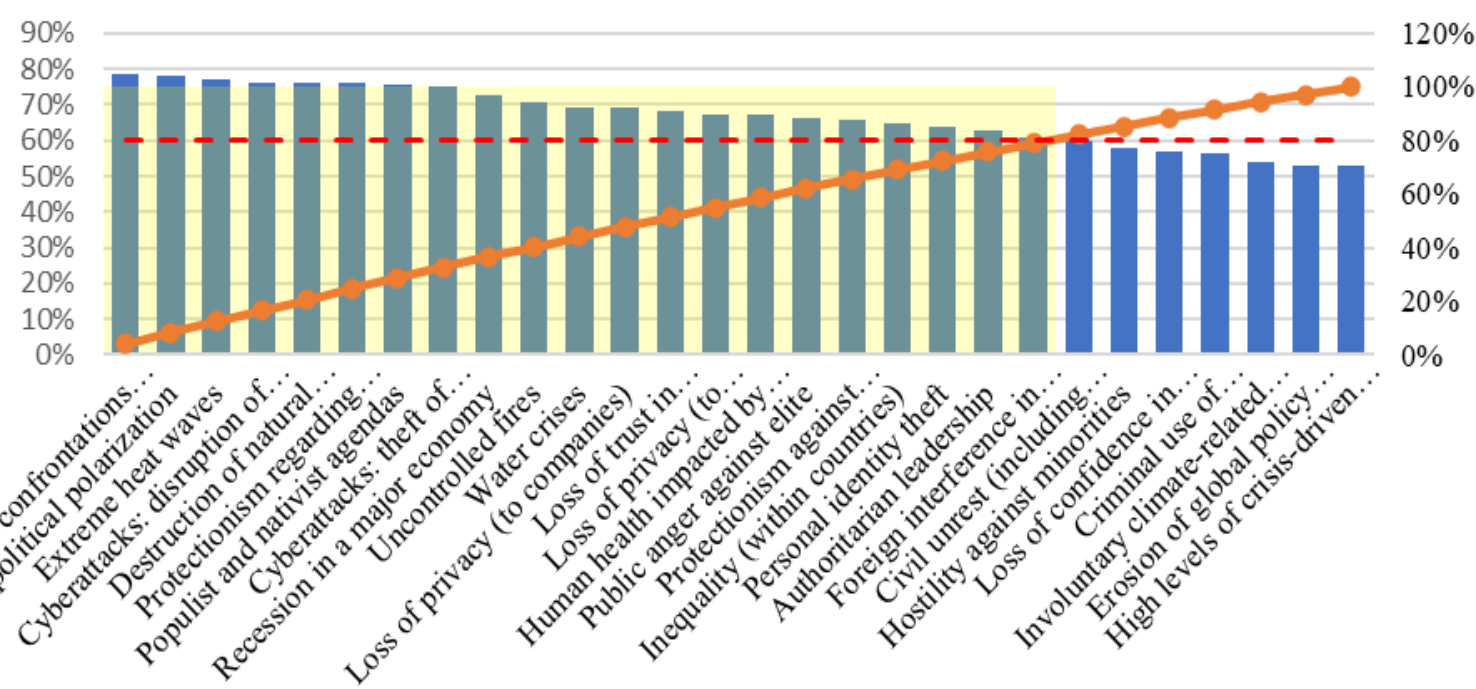

The protective function is due to the business entity's ability to seek and use a variety of tools and methods to prevent losses due to the implementation of risks, namely in the form of legal, political, economic guarantees or social protection.

The manifestation of the regulatory function of risk is manifested in its ability to influence the firm's activities by continually studying the risky situation, predicting the degree of risk, and adjusting decisions already made. In this case, a distinction is made between constructive (positive influence by stimulating innovative activity) and destructive manifestation of the regulatory function (negative impact in increasing the probability of incurring losses due to making unreasonable decisions and ignoring risks).

The analytical function of risk is realized in the need for the business entity to carry out analytical work in the decision-making process through intuition, past experience, or unusual analysis methods to make optimal decisions and avoid losses.

\section{Results and discussion.}

Integrated risk management allows the entity to achieve its strategic goals and provides for the unity of the risk management system and general administrative management.

The proposed emergency risk management mechanism is shown in Fig. 5. The primary purpose of risk management is to reduce or eliminate possible losses from risk. The main principles of risk management are as follows:

- the principle of scale (maximization) - is to strive to take into account as many areas of possible risks of emergencies;

- the principle of minimization is to reduce the range of manifestations of risks and the degree of their impact;

- the principle of adequate response is a quick and effective response to changes in the risk situation;

- the principle of reasonable acceptance is to accept the risk only if it is reasonably necessary.

Based on the identification and assessment of enterprise risks, a decision is made to apply appropriate economic methods to reduce the degree of risk. In world practice, many different and entirely original ways and means of reducing risk have been developed. However, the main effective 
risk management areas include avoidance, equalization, preservation, reduction, and risk transfer. These methods are not mutually exclusive so that they can be used simultaneously.

Figure 5. Emergency risk management mechanism

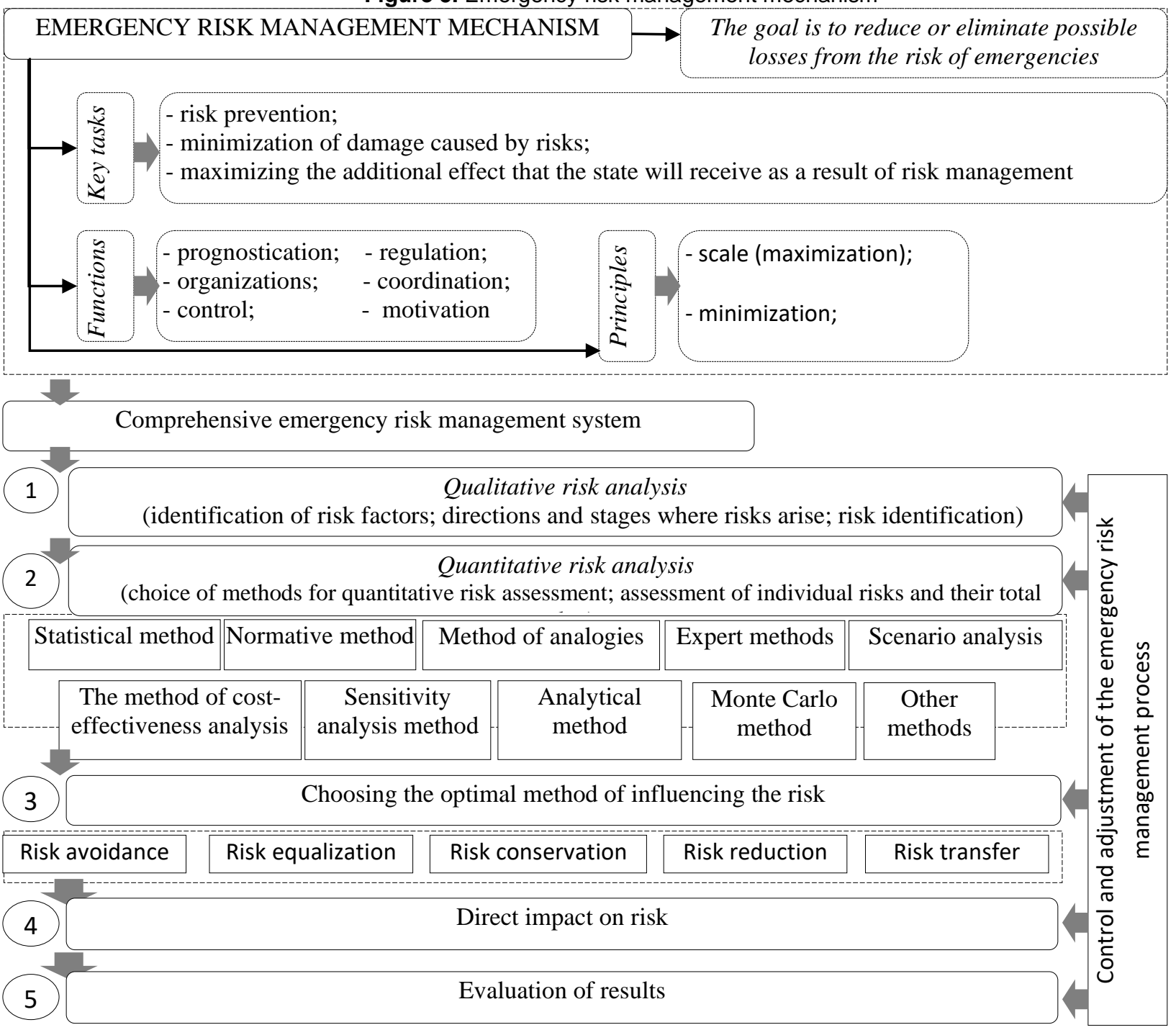

The risk management strategy contains rules based on which ways to choose a solution in risk situations are proposed:

1. Maximum winnings.

2. Optimal probability of the result.

3. Optimal fluctuation of the result.

4. The optimal combination of gain and magnitude of risk (Fig. 6).

The rules for choosing a solution in risk situations are supplemented byways to select a solution. Among them are the following

a) Choice of the solution, provided that the probabilities of possible other emergencies are known

b) Choice of the solution, provided that the probabilities of possible other emergencies are unknown, but there are estimates of their relative values.

c) Choosing the solution, provided that other emergencies' probabilities are unknown, but there are basic directions for evaluating the results. 
Figure 6. Rules for choosing a risk management strategy for emergencies

The rule of maximum protection is that the one that gives the most significant effects of the result for the preservation of life, nature, resources with minimal or acceptable risk is chosen from the possible risk options.

\begin{tabular}{l}
$\begin{array}{c}\text { The rule of the optimal } \\
\text { combination of gain and risk } \\
\text { is to estimate the expected values } \\
\text { of gain and risk, deciding to invest } \\
\text { in a project that allows you to get } \\
\text { the expected result and at the } \\
\text { same time avoid high risk and } \\
\text { human losses. } \\
\text { The rule of optimal oscillation of the result in practice is combined with the rule of the optimal } \\
\text { probability of the result: their variance, standard deviation, express fluctuations of indicators. From the } \\
\text { possible solutions, the one in which the possibility of winning and losing for the same risk event has a } \\
\text { small gap, i.e. the smallest value of variance, standard deviation, and variation. } \\
\text { probability of the result } \\
\text { is that the one is chosen } \\
\text { from the possible decisions } \\
\text { in which the probability of } \\
\text { the result is acceptable for } \\
\text { the society/person making } \\
\text { the decision. }\end{array}$ \\
\hline
\end{tabular}

\section{Conclusion.}

The information sphere, being a system-forming factor in the world community's life, actively influences the state of political, economic, military-strategic and other components of security. The structure of the security of emergencies essentially depends on ensuring information security, and in the course of technological progress, this dependence will increase. Information technologies are becoming one of the most important factors in the modern world's management, the main instrument of power influencing the existing system of international relations and transforming the very concept of both national and international security.

At the present stage, Ukraine is just beginning the digital transformation path by the requirements of the digital economy, while most areas are already approaching global standards of digital governance. Thus, the need to develop a comprehensive model of public administration in the framework of digitalization and digital transformation is beyond doubt. Based on the substantiation of positive foreign experience, it is possible to state the practicality of introducing a new digital public management model in Ukraine, which would take into account all the challenges of the network economy. The fundamental problem of further research may be that the new model's central body will not be able to deal with all the issues concerning decision-making due to the implementation of such a model. Simultaneously, there is a high probability of a shortage of specialized managers with modern managers' professional functions.

\section{References}

1. Albornoz, S.C. \& Chen, G. (2021). Relationship between health-related quality of life and subjective wellbeing in asthma. Journal of Psychosomatic Research, 142, Article number 110356.

2. Bashynska I. \& Levinska L. (2017). The theoretical substantiation of the economic essence of the category "risk". Economy. Finances. Law., 10/1'2017, pp. 66-68. 
3. Filyppova S. et al. (2019). Risk management through systematization: Risk Management Culture, International Journal of Recent Technology and Engineering, Volume-8 Issue-3, Sep. 2019, pp. 6047-6052 DOI: 10.35940/ijrte.C5601.098319

4. Gavurova, B. et al. (2021). Strategic Management in SMEs and Its Significance for Enhancing the Competitiveness in the V4 Countries-A Comparative Analysis. Management and Marketing, 15(4), pp. 557-569.

5. Gibesova, B. et al. (2017). Formation of a complex of management decisions on the reduction of environmental pollution during the development of coal mines. Problems and Perspectives in Management, 15(2), pp. 246-254.

6. Halkiv, L. et al. (2020). Modeling and forecasting of innovative, scientific and technical activity indicators under unstable economic situation in the country: Case of Ukraine. Communications in Computer and Information Science, 1158, pp. 79-9. https://doi.org/10.1007/978-3-030-616564_5

7. Ibrahim, M.D. et al. (2021). A two-stage data envelopment analysis of efficiency of socialecological systems: Inference from the sub-Saharan African countries. Ecological Indicators, 123, Article number 107381.

8. Kuzmenko, H. et al. (2019). The experimental model of procurement in public administration. International Journal of Innovative Technology and Exploring Engineering, 8(11), pp. 2773-2778.

9. Margasova, V. \& Rogovyi A. (2010). Financial risks in functioning of management system at jointstock companies. Actual Problems of Economics, (1), pp. 136-142.

10.Mura, L. et al. (2015). Quantitative financial analysis of small and medium food enterprises in a developing country. Transformations in Business and Economics, 14(1), pp. 212-224.

11.Prokopenko, O. \& Miśkiewicz, R. 2020. Perception of "Green Shipping" in the contemporary conditions. Entrepreneurship and Sustainability, 8(2), pp. 269-284. https://doi.org/10.9770/jesi.2020.8.2(16)

12.Saługa, P.W. et al. (2020). Cost of Equity of Coal-Fired Power Generation Projects in Poland: Its Importance for the Management of Decision-Making Process. Energies. 13(18), 4833. https://doi.org/10.3390/en13184833

13.Seilerová, M. (2019). The Consequences of Psychosocial Risks in the Workplace in Legal Context. Central European Journal of Labour Law and Personnel Management, 2 (1), 47-60. http://doi.org/10.33382/cejllpm.2019.02.04

14.World Econonic Forum. The Global Risks Report 2020. Available at: http://www3.weforum.org/docs/WEF_Global_Risk_Report_2020.pdf 